\title{
Native Vegetation
}

\author{
Murat Özyavuz, Aslı B. Korkut \\ and Ayten Özyavuz
}

Additional information is available at the end of the chapter

http://dx.doi.org/10.5772/55813

\section{Introduction}

Biodiversity is the diversity of life in all its forms across the planet. The National State of the Environment Report made the following statements in defining biodiversity (Slattery, et al., 2003):

"Biodiversity is the variety of all forms of life - the different plants, animals and microorganisms, the genes they contain and the ecosystems of which they form a part".

It ranges from large scale ecosystems to the different species of flora and fauna, and to genetic differences between individuals of the same species. These three levels work together to create the complexity of life on earth. Accordingly, biodiversity is conventionally partitioned into three components: (1) genetic diversity, (2) species diversity and (3) diversity of ecosystems (Slattery, et al., 2003).

\section{Genetic diversity}

Genetic diversity is normally considered to be the range of genetic information present within a species. Genetic information is passed on to successive generations either directly in asexual reproduction or by mixing of genetic material from both parents in sexual reproduction. Genetic diversity increases the diversity of form and behavior within a species, which provides it with greater capacity to cope with changing environmental conditions or make use of completely different environments. Genetic diversity may be expressed in the form of genetic variation within individuals, within populations and/or between populations. Genetic diversity can decline if populations are lost or if the total population of the species is drastically reduced. If populations become fragmented into very small sub-populations, inbreeding depression may cause the genetic diversity to decline further (Smith, et. al., 2000). 


\section{Species diversity}

The number of species present in a location depends on the type of ecosystem. Subtropical rainforests usually contain over 100 vascular plant species in a hectare, including 30-40 tree species, whereas a hectare of cool temperate rainforest may contain only 5-10 tree species. Grassy woodlands and heaths may also be diverse with more than 100 species in a hectare, although sometimes these vegetation types contain relatively few species. However, ecosystems with relatively few species, such as temperate rainforests, can be important for species diversity if those species are unique. The diversity of various animal species assemblages varies even more than that of plants, and some groups also show distinct seasonal variation (Smith, et. al., 2000) (Figure 1.).
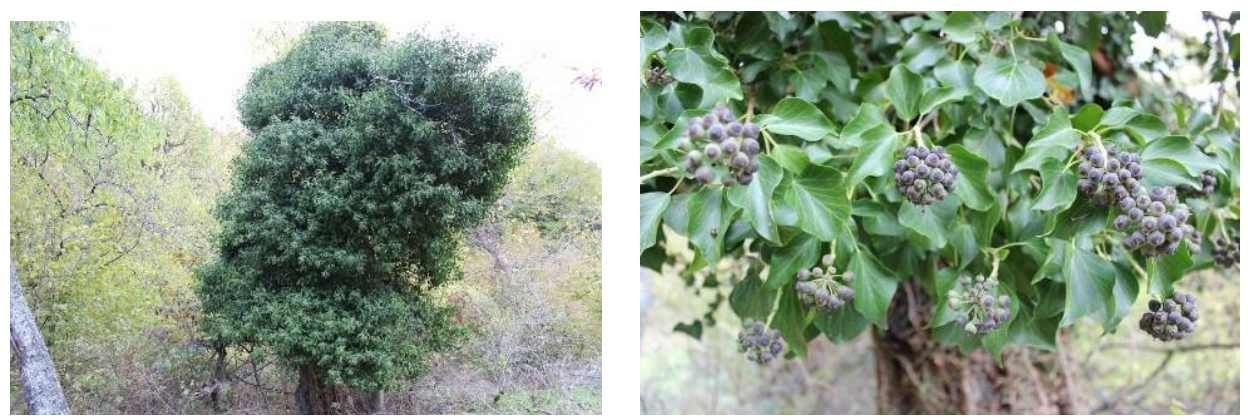

Figure 1. Hedera colchica (This plant is covered Prunus avium and has taken its place)

\section{Diversity of ecosystems}

The species in a given area interact with each other and with their environment to form complex networks known as ecosystems. These differ from place to place, thus creating ecosystem diversity. Each ecosystem differs from all others because it contains a unique combination of species (and therefore genes) and because these species interact with each other and with each environment in distinctive ways. Biodiversity is not static but is constantly changing. It is increased by genetic change and evolutionary processes and reduced by processes such as habitat degradation, a decline in flora and fauna, and the extinction of species. Diversity in all its forms (genetic, species and ecosystem) is a critical factor in the resilience of an area and its ability to respond to significant changes such as fire, food, climate and human impacts. Diversity is the key to maintaining viable populations of our native flora and fauna (Environmental Protection Authority, 2000) (Figure 2).

This is due to three major components, loss of biodiversity can result in reduction or loss of ecosystem function. Therefore, it is very important the need for conservation of biodiversity. There are four main reasons for preserving biodiversity: maintaining ecosystem processes, ethics, aesthetics and culture, and economics (Environmental Protection Authority, 2000).

Biodiversity has two key aspects:

- $\quad$ its functional value at the ecosystem level; and

- $\quad$ its intrinsic value at the individual species, species assemblages and genetic levels. 


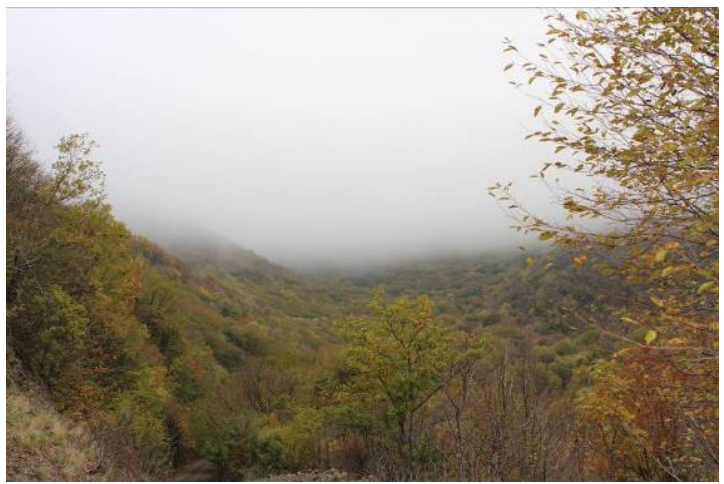

Figure 2. With a variety of important plant Ganos Mountain, Tekirdag, Turkey

The functional value is derived from the parts played by the species assemblages in supporting ecosystem processes and is expressed through the kinds of plant and animal assemblages occurring in various parts of the landscape on different soil types. In addressing this, matters requiring consideration include (Environmental Protection Authority, 2000):

- soils;

- landscape;

- $\quad$ species richness;

- $\quad$ species composition;

- differences in composition pre and post disturbance; and

- the ecosystem processes, linkages and how they are supported.

The intrinsic values relate to the actual species and species associations. Two species assemblages may have different intrinsic values but may still have the same functional value in terms of the part they play in maintaining ecosystem/ecological processes (Environmental Protection Authority, 2000).

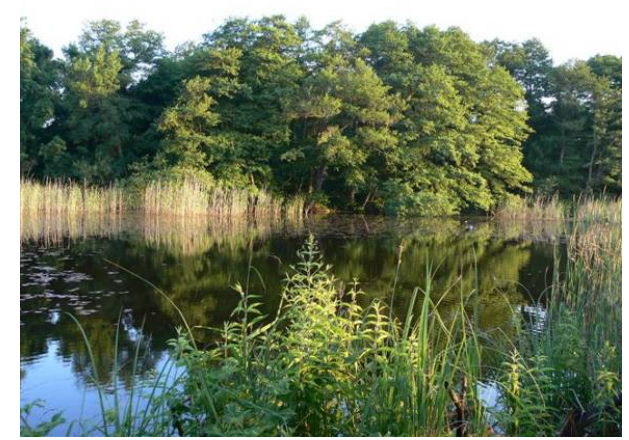

Figure 3. The Saka Lake, İğneada, Kırklareli, Turkey (It is an important area for a variety of birds and plants) 
Biodiversity provides the critical processes that make life possible, and that are often taken for granted. Healthy, functioning ecosystems are necessary to maintain the quality of the atmosphere, and to maintain and regulate the climate, fresh water, soil formation, cycling of nutrients and disposal of wastes (often referred to as ecosystem services). Biodiversity is essential for controlling pest plants, animals and diseases, for pollinating crops and for providing food, clothing and many kinds of raw materials (Environmental Protection Authority, 2000).

Biodiversity refers to the living pieces that shouldn't be discarded since we use the earth's resources to sustain us. Experience suggests to us that the first rule of intelligent tinkering is to keep all of the pieces. Because of the interconnected nature of ecosystems, the loss or addition of one species has the potential to change an ecosystem.

- High levels of biodiversity are associated with greater ecosystem stability. The more diverse a system is, the better able it is to cope with environmental stressors, such as floods or drought. Biodiversity gives us choices, options and flexibility to help us cope with variability, including long-term habitat changes.

- When a system is simplified, such as having only one species of crop or type of grass, it increases the odds that environmental stressors will have a more pronounced impact or that a disease or pest will be able to spread rapidly. Animal and plant populations with low genetic diversity are much more susceptible to stress and vulnerable to extinction.

- We all rely on the tremendous variety of species, genes and ecosystems in our world and the many benefits we receive from them - they deserve our respect and conservation.

\section{The Importance of Biodiversity}

Potential benefits of biodiversity are; health of ecosystems, their ability to maintain and regulate atmospheric quality, climate, fresh water, marine productivity, soil formation, cycling of nutrients and waste disposal, Resilience of ecosystems, their ability to respond to and recover from external shocks such as drought, flood, and climate change, cultural values (Figure 4). Biodiversity is extremely important to people and the health of ecosystems. A few of the reasons are (National Wildlife Federation, 2013):

- Biodiversity allows us to live healthy and happy lives. It provides us with an array of foods and materials and it contributes to the economy. Without a diversity of pollinators, plants, and soils, our supermarkets would have a lot less produce.

- Most medical discoveries to cure diseases and lengthen life spans were made because of research into plant and animal biology and genetics. Every time a species goes extinct or genetic diversity is lost, we will never know whether research would have given us a new vaccine or drug.

- Biodiversity is an important part of ecological services that make life livable on Earth. They include everything from cleaning water and absorbing chemicals, which wetlands do, to providing oxygen for us to breathe-one of the many things that plants do for people. 
- Biodiversity allows for ecosystems to adjust to disturbances like extreme fires and floods. If a reptile species goes extinct, a forest with 20 other reptiles is likely to adapt better than another forest with only one reptile.

- Genetic diversity prevents diseases and helps species adjust to changes in their environment.

- Simply for the wonder of it all. There are few things as beautiful and inspiring as the diversity of life that exists on Earth.

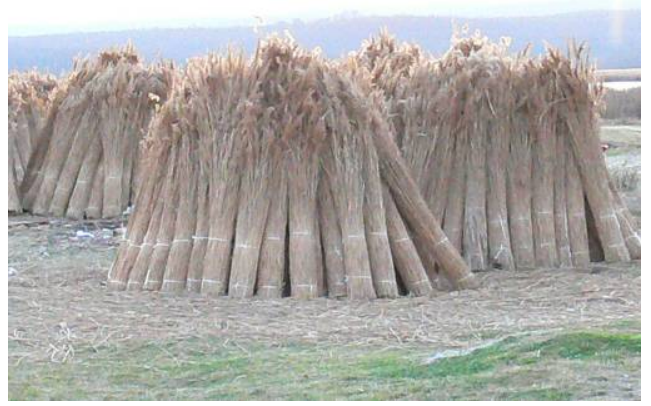

Figure 4. Reedy areas, is applied to the regular cutting program has an important economic function.

\section{Threats to Biodiversity}

Extinction is a native part of life on Earth. Over the history of the planet most of the species that ever existed, evolved and then gradually went extinct. Species go extinct because of native shifts in the environment that take place over long periods of time, such as ice ages.

Today, species are going extinct at an accelerated and dangerous rate, because of non-native environmental changes caused by human activities. Some of the activities have direct effects on species and ecosystems, such as are (National Wildlife Federation, 2013):

\section{Habitat loss/ degradation}

When an ecosystem has been dramatically changed by human activities - such as agriculture, oil and gas exploration, commercial development or water diversion - it may no longer be able to provide the food, water, cover, and places to raise young. Every day there are fewer places left that wildlife can call home (Figure 5). There are three major kinds of habitat loss are (National Wildlife Federation, 2013):

- Habitat destruction: A bulldozer pushing down trees is the iconic image of habitat destruction. Other ways that people are directly destroying habitat, include filling in wetlands, dredging rivers, mowing fields, and cutting down trees.

- Habitat fragmentation: Much of the remaining terrestrial wildlife habitat in the U.S. has been cut up into fragments by roads and development. Aquatic species' habitat has been fragmented by dams and water diversions. These fragments of habitat may not be large or connected enough to support species that need a large territory in which to find 
mates and food. The loss and fragmentation of habitat make it difficult for migratory species to find places to rest and feed along their migration routes.

- Habitat degradation: Pollution, invasive species and disruption of ecosystem processes (such as changing the intensity of fires in an ecosystem) are some of the ways habitats can become so degraded that they no longer support native wildlife.

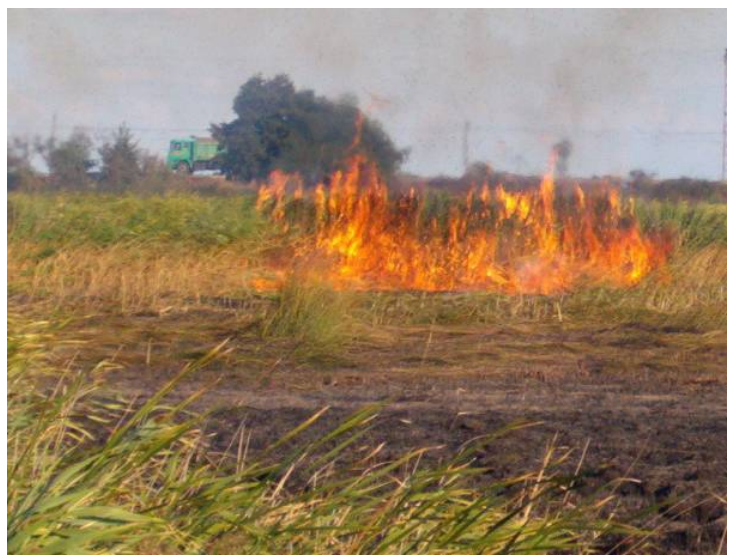

Figure 5. Applied to the wrong policies of nature conservation, local communities could lead to damage to the environment.

\section{Over exploitation (such as overfishing)}

People have always depended on wildlife and plants for food, clothing, medicine, shelter and many other needs. But today we are taking more than the native world can supply. The danger is that if we take too many individuals of a species from their native environment, the species may no longer be able to survive. The loss of one species can affect many other species in an ecosystem. Overexploitation is the over use of wildlife and plant species by people for food, clothing, pets, medicine, sport and many other purposes. The hunting, trapping, collecting and fishing of wildlife at unsustainable levels is not something new. The passenger pigeon was hunted to extinction early in the last century, and overhunting nearly caused the extinction of the American bison and several species of whales. Today, the Endangered Species Act protects some U.S. species that were in danger from overexploitation, and the Convention on International Trade in Endangered Species of Fauna and Flora (CITES) works to prevent the global trade of wildlife. But there are many species that are not protected from being illegally traded or overharvested are (National Wildlife Federation, 2013).

\section{Spread of Non-native Species/ Diseases}

Human health and economies are also at risk from invasive species. The impacts of invasive species on our native ecosystems and economy cost billions of dollars each year. Many of our commercial, agricultural, and recreational activities depend on healthy native ecosystems.

Some human activities have indirect but wide-reaching effects on biodiversity, including: 
- Climate change

- Pollution

All of these threats have put a serious strain on the diversity of species on Earth. According to the International Union for Conservation of Nature (IUCN), globally about one third of all known species are threatened with extinction. That includes $29 \%$ of all amphibians, $21 \%$ of all mammals and $12 \%$ of all birds. If we do not stop the threats to biodiversity, we could be facing another mass extinction with dire consequences to the environment and human health and livelihood are (National Wildlife Federation, 2013).

\section{Native Vegetation}

In an area without anthropogenic influences, vegetation consisting of completely native causes "native vegetation" is called. Anthropogenic impacts on vegetation by humans and animals all the destroyed (cut plants, fires, grazing, irrigation and drying of areas of life, such as climate change).

A lot of people from the intensification of economic activities in the world, after the last 50 years, especially with the increasing environmental pollution, anthropogenic influences largely been talk of a distant vegetation. The world's most secluded and found not the people living in the bodies of living things, even if the environmental pollution caused by the accumulation of many chemicals were transported. For these reasons, today, even the anthropogenic impact in less developed regions is still far from human influence.

Description of the plant natively grows only in certain areas of native vegetation, but also to be expressed in those areas should be moved by the people. Native plants in geological times in a region that region-specific climate, soil, rainfall, drought and frost, depending on the physical and biotic characteristics evolve and interact with other species in that region are found in the local plant communities. In this way, the conditions under which native plants will have certain features that makes them perfectly adapted to the characteristics and landscaping, conservation and restoration projects is extremely important to provide alternatives.

Plant sociologists, often talking about the native vegetation of different "Potential Native Vegetation". Potential Native Vegetation, all the external influences in an area (anthropogenic effects) resulting from native plant cover is removed. Generally, founded by ancient civilizations such as Turkey, passed away of native resources and areas of use, this day there are big differences between vegetation and native vegetation. However, in areas that are difficult to reach believers hardly influence the high mountains and vegetation, is equivalent to the present.

The material is of great importance for landscaping with native plants and plant communities that make us the main ones are as follows: Forests, savannah, maquis, savannahs, deserts, meadows, tundras, alpine plants, swamps. These are usually the most important plant communities that make up the earth, ecological sense, have come together and established a partnership between the livings, rather than growing the plant complied evaluated in terms of their formation and utilization conditions. 
Development of vegetation in an area and constantly remain in the area of environmental conditions that have an impact on the router. Environmental conditions, climatic conditions generally (temperature, humidity, rainfall, light, wind, etc.)., edaphic conditions (soil, water), orographic conditions (pressure area, slope, elevation, etc.)., biotic conditions (the effect of the surrounding creatures) is understood. Environment, living environment, "Biyosenoz" and the non-living environment "Ecotope" ecosystem, which together are called. Ecotopes a harmonious balance between native surroundings and has biyosenoz. At the end of the evolution of ecosystems composed of many years in this environment and vegetation is appropriate that this "Klimax" is called. There is one or more of the conditions that make the environment as a result of changes in the plant community, especially, are seen in the changing ecosystem. For these reasons, making any assessment of the vegetation in an area that should be examined thoroughly the effects of local environmental conditions and their vegetation.

Plants form the key elements stored in the primary energy production. All living things depend on other living plants. Native plants natively occur in the region in which they evolved. While non-native plants might provide some of the above benefits, native plants have many additional advantages. Because native plants are adapted to local soils and climate conditions, they generally require less watering and fertilizing than non-natives. Natives are often more resistant to insects and disease as well, and so are less likely to need pesticides. Wildlife evolved with plants; therefore, they use native plant communities for food, cover and rearing young. Using native plants helps preserve the balance and beauty of native ecosystems (Figure 6.).

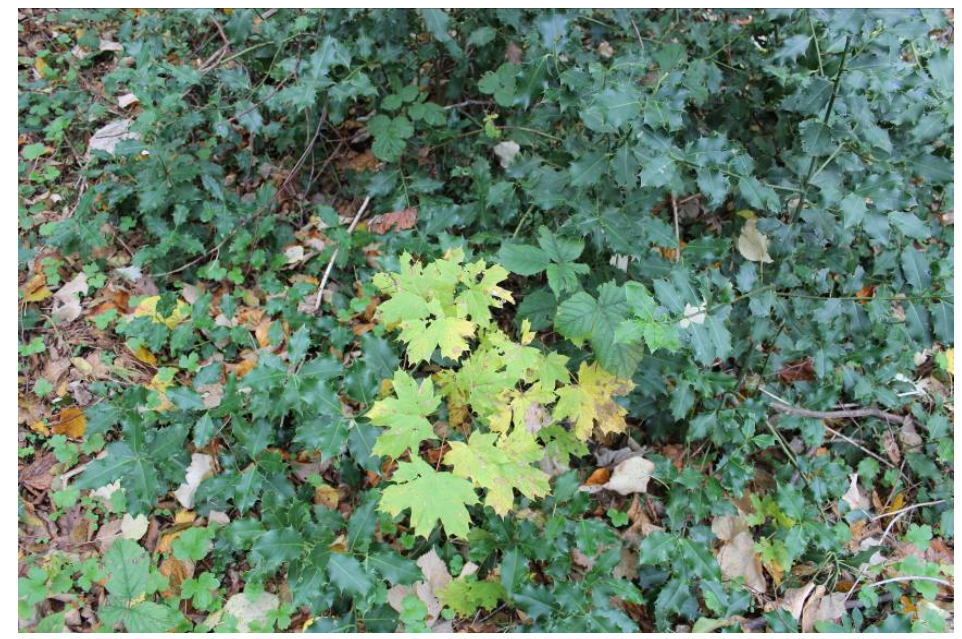

Figure 6. Different plant species in small area (Acer platanaoides, Hedera helix, Illex aquifolium, Rubus sp.)

Native species are those that occur in the region in which they evolved. Plants evolve over geologic time in response to physical and biotic processes characteristic of a region: the 
climate, soils, timing of rainfall, drought, and frost; and interactions with the other species inhabiting the local community. Thus native plants possess certain traits that make them uniquely adapted to local conditions, providing a practical and ecologically valuable alternative for landscaping, conservation and restoration projects, and as livestock forage. In addition, native plants can match the finest cultivated plants in beauty, while often surpassing non-natives in ruggedness and resistance to drought, insects and disease (Virginia Department of Conservation \& Recreation, 2012) (Figure 7.).

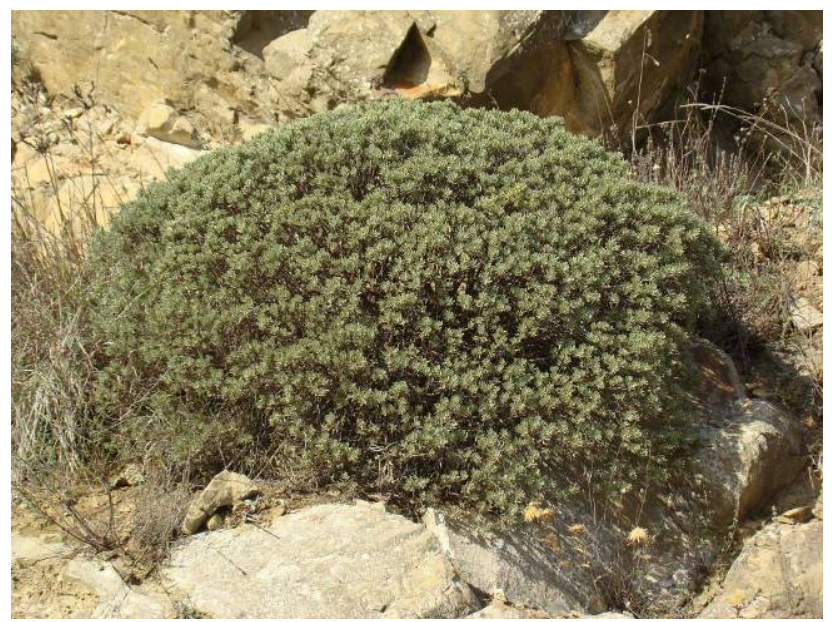

Figure 7. Thymelaea tartonraira an important plant in arid area

Native vegetation is defined differently in different jurisdictions but typically is defined to include natively occurring local vegetation (in some cases defined as vegetation that existed before a certain date), including in some jurisdictions native grasses and aquatic vegetation. The definition of terms such as 'remnant', 'regrowth', and 'thickening' is more contentious. (Productivity Commission, 2004).

\section{Potential benefits of Native vegetation}

- Fodder; food; seeds; wildflowers and plants; medicines; timber, including for fencing and firewood; shade; shelter; honey production; pollination and pest control services

- Tourism, recreation and visual amenity

- Habitat for native fauna (Figure 8)

- Soil and water protection (eg prevention of salinity, soil erosion or acidification)

- Biodiversity

- Carbon sinks and/or storage

- Climate

- 'Existence' and 'option' values (Productivity Commission, 2004).

In other words, native vegetation is;

- Oxygen production is the largest function. 


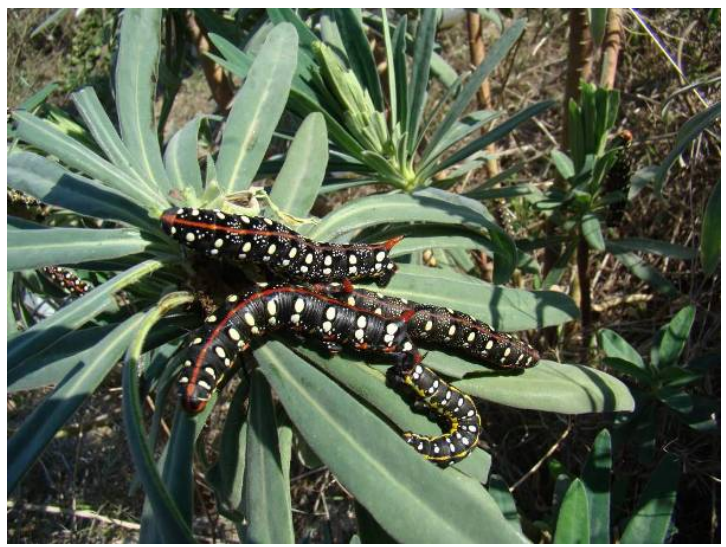

Figure 8. Larva fed on leaves of Euphorbia sp.

- The native vegetation is important in terms of microclimatic effects.

- It is important in relation to hydrological events.

- I is important in relation to soil

- It is home to wildlife

- It is high and significant economic value.

- It is important in relation to recreational (Figure 9)

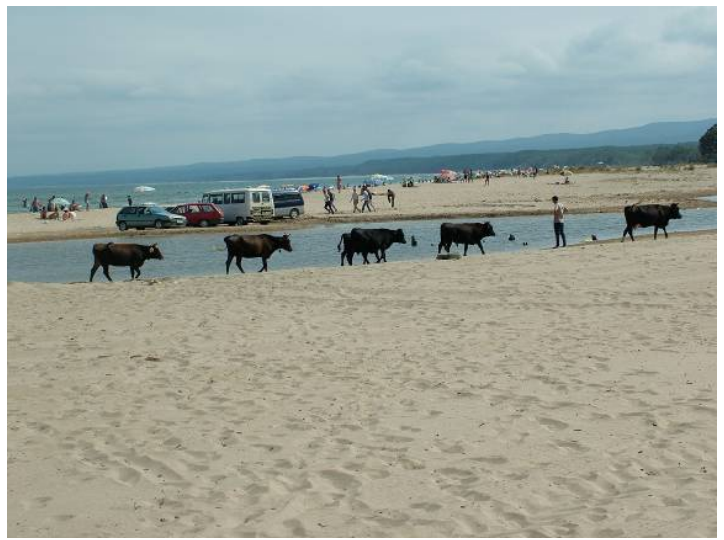

Figure 9. Sand dune areas are important for recreational activates.

Native vegetation provides many benefits principally through the protection of the land surface, amelioration or modification of local climate, maintenance of critical ecosystem processes, conservation of biodiversity, enhancement and protection of cultural and aesthetic values, and the provision of economically important products such as timber and grazing forage. However, significant degradation and loss of native vegetation has taken place since European settlement, principally as a result of human activity (Smith, et. al., 2000). 
The native vegetation is directly related to land use and environmental change and is the most easily visible and perceived part of the landscape. It is important in relation to visual effects. However, without detailed studies cannot be understood fully the relationship between other landscape elements. According to Peter et al. (2000), as well as providing essential habitat, native vegetation, including small isolated remnants and scattered trees, has an important role in providing connectivity across the landscape (Figure 10).

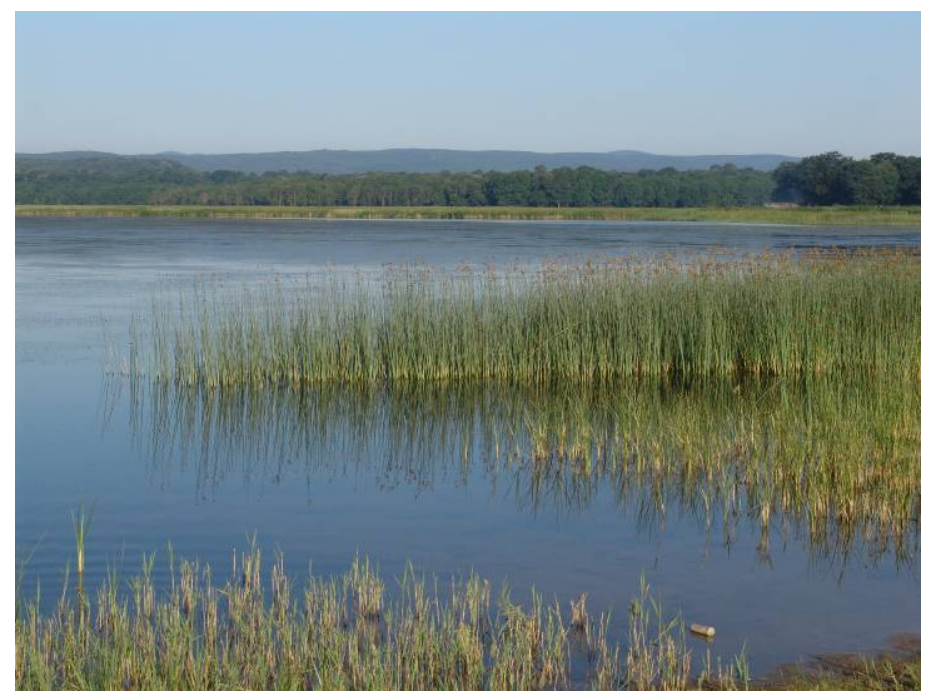

Figure 10. The Mert Lake, İğneada, Kırklareli, Turkey

According to (Smith, et. al., 2000); Connectivity concerns how easily the landscape allows plant and animal species to disperse or move through it. Adequate connectivity in the landscape reduces the probability of small isolated populations occurring, allows mobile species to access essential but dispersed resources, and may be important for species migration. Connectivity needs to be considered on a whole-of-landscape basis. This is because species movement can occur from any patch or island that is either large enough or of sufficient habitat quality to support a breeding population or among a number of smaller patches that combine to provide suitable habitat for a population. Corridors are generally considered important for providing connectivity in highly cleared and fragmented landscapes (Fahrig and Merriam 1985, Downes et al. 1997). However, there is only limited proof of their efficacy in allowing species movement and they may indeed negatively affect individual species by promoting transmission of diseases and disturbances (Simberlof and Cox 1987, Hess 1994). Nevertheless, it is generally agreed that species response to fragmentation is individualistic and that corridors enhance landscape connectivity for many species (Saunders et al. 1991, Dawson 1994, Beier and Noss 1998).

According to (Smith, et. al., 2000); Native vegetation plays an important role in many ecosystem processes. These processes include nutrient retention and cycling, carbon storage, purification of water and the maintenance of viable and diverse populations of important 
components of biodiversity such as detritivores (organisms that break down organic matter) pollinators and parasites and predators of farm pests (Figure 11). For example the life cycle of some parasitic wasps and flies depend on nearby sources of food found in native vegetation. Some species of these parasites seldom travel more than 200 metres from such sources of food (Davidson and Davidson 1992).

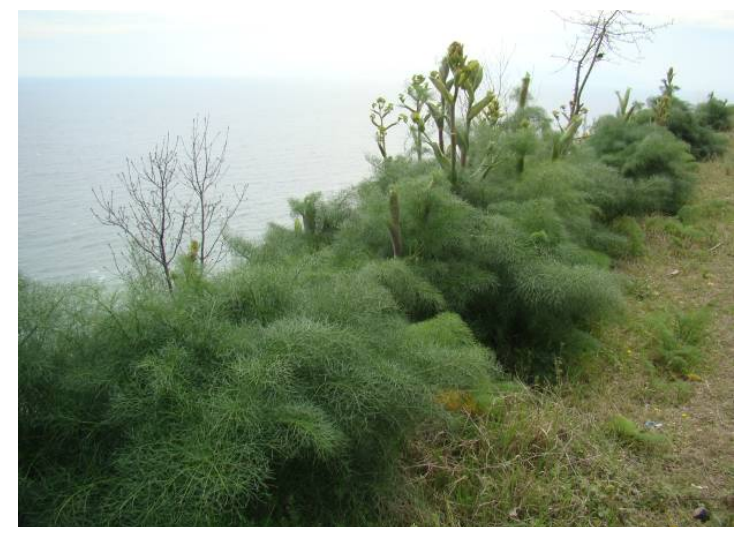

Figure 11. Ferula communis subsp.communis is used in pharmaceutical industry

Degradation and loss of native vegetation resulting from human activity has altered and disturbed many of these ecosystem processes. Broad-scale loss of vegetation cover has led to considerable land degradation by exposing the land surface to wind and rainfall, which greatly increases soil erosion. These problems are exacerbated by some agricultural management practices, which cause loss of soil organic matter and nutrient decline and, in some places, increasing soil salinity and acidity. For example, it has been estimated that some 120,000 ha of NSW are currently affected by salinity and that 7.5 million ha could potentially become salt affected (Smith, et. al., 2000).

Disturbance of ecosystem function, fragmentation of habitats, the introduction of foreign species and ecologically unsympathetic agricultural systems has been widespread. As a consequence, species decline and extinction has been marked, while altered community balance has frequently led to the unchecked and damaging spread of exotic plants and animals. Halting the decline in native vegetation cover and rectifying some of the damage that has been done is not an easy task, but is possible. Nature reserves have a vital role in this recovery but are only part of the solution. We also need sympathetic management of privately owned native vegetation, and it should be recognised that such management can offer production benefits by preserving land and water quality. Restoration of vegetation cover also provides considerable potential for improved ecosystem function, increased biodiversity and better health for the wider environment (Smith, et. al., 2000).

\section{Benefits of native vegetation}

Biodiversity conservation is an essential component of responsible environmental and native resource management. It is fundamental to quality of life and supports our economy 
and productivity, both now and in the future. Native vegetation provides habitat for native animals. It delivers a range of ecosystem services that make the land more productive and that contribute to human wellbeing. The benefits provided by native vegetation can be separated into the following categories (Victorian Government Department of Sustainability and Environment, 2012).

Use values

Use values involve people physically using or experiencing native vegetation and the attributes it provides, and deriving value from this use. These use values comprise both direct use values and indirect use values.

Direct use values. These values include benefits to agricultural production, such as enriching soils, shade for animals, pollination of plants, and native vegetation as the provider of goods such as honey, timber and pasture for grazing. Other direct uses of native vegetation include recreation and cultural uses.

Indirect use values. These values include functional benefits derived from relying on native ecosystems for life support functions including providing clean air, water and other resources, along with the conservation of biodiversity. Other benefits include resilience to climate change, and reduced susceptibility to disease and extreme weather events.

\section{Non-use values}

There are a range of benefits that flow from native vegetation that are enjoyed without contact with the native vegetation. These are known as non-use values and include existence values, option values and bequest values (Victorian Government Department of Sustainability and Environment, 2012).

- Existence values. This means the satisfaction that the community derives simply from knowing that native vegetation and biodiversity exist.

- Option values. These are benefits derived from retaining the option to use native vegetation in the future without necessarily planning to do so. These benefits include the value of waiting until a time in the future when better information is available to inform decisions about the use of native vegetation.

- Bequest values. These values derive from the knowledge that maintaining native vegetation and biodiversity will benefit future generations. (Victorian Government Department of Sustainability and Environment, 2012).

\section{Identification and classificiation of native vegetation}

The aim is to determine the extent of the formation and vegetation. Classificiation table is;

1. Floristic:As an individual species, genera, families and so on. to classify the botanical names of the form

2. Form and structure: This is based on the dominant forms (forest, pasture etc.) of plant communities by giving importance to classify plants (the most abundant, etc.)

3. Ecological: This classification, to classify plants according to habitat and some of the critical environmental parameters. 


\section{Turkey and Native Vegetation}

Biodiversity is the great wealth of the countries that have the most perceived. Turkey is the world's richest in terms of native vegetation one of the countries. Mediterranean, IranoTuranian and Euro-Siberian phytogeographical regions of Anatolia into finding and intertwined with each other, this is the main cause of wealth.

Meadows and pastures in our country is one of the most important sources of biological diversity. These are considered one of the largest renewable native resources. Turkey, in terms of plants in the world, is one of the countries in the temperate climate zone. The main reasons for this wealth, climate differences, topographical diversity, geological and geomorphological diversity, sea, lake, river, such as various water variety of environments, ranging from 0-5000 meters height differences, three different combined with the fact that the place of plant geography, east and west of Anatolia differences between the present ecological and floristic diversity in all of these ecological reflection of the diversity (Figure 12).

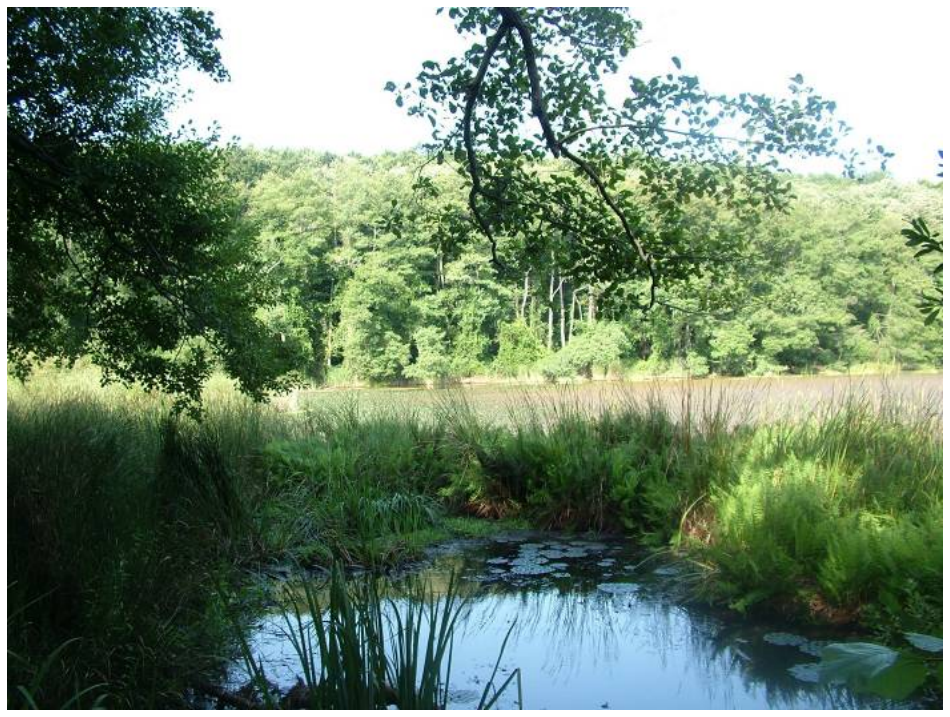

Figure 12. The Hamam Lake, İğneada, Kırklareli (the lake in forest)

Turkey, around 9000 with the type of ferns and seed plants is a country very rich in terms of flora. Whereas, flora of the European continent contains about 12,000 species. The importance of the flora of Turkey, as well as species richness is due to the high rate of endemism. There are 2750 endemic species in the European countries, Turkey, this number is around 3000 (Figure 13).

In our country, the factors leading to the formation of native vegetation regions of Anatolia, depends on the structure of a specific native. The first of these stages of the country that are turning very sharp elevation in mountainous morphological structure. Accordingly, in the 
north, north west, south of the south-westerly winds, the creation of different climates. Therefore, the vegetation varies in the vertical direction only, but also by looking also varies widely (Figure 14).

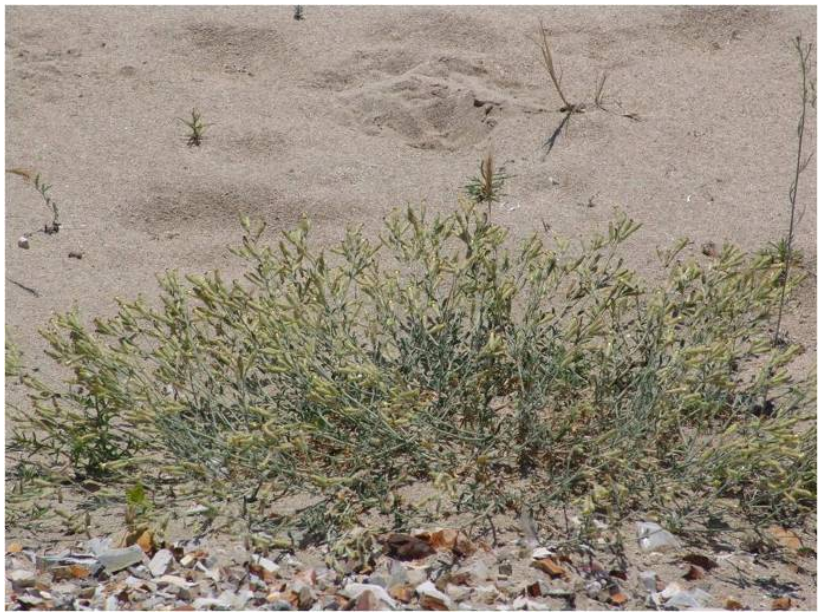

Figure 13. Silene sangaria Coode $\&$ Cullen (endemic)

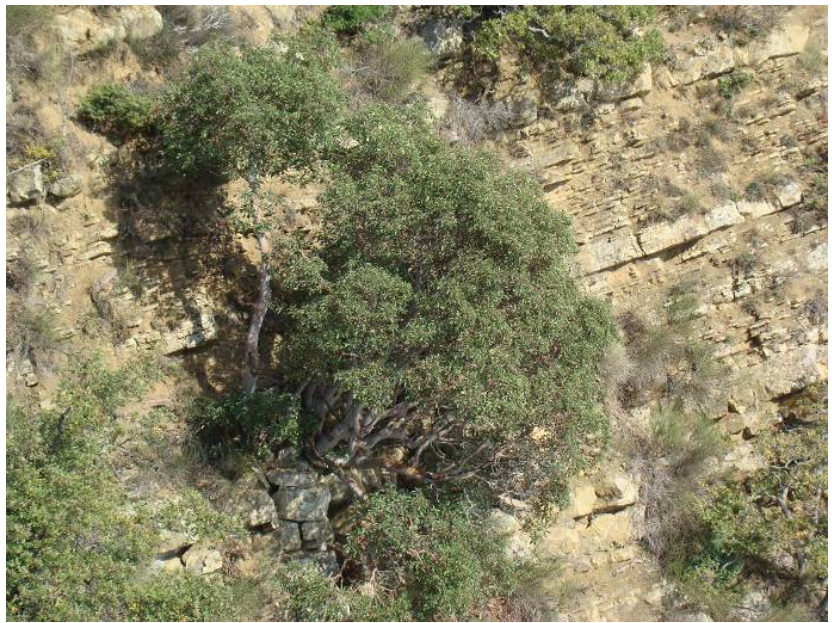

Figure 14. Arbutus andrachne L. (Southern slopes overlooking the sea), Ganos Mountains, Tekirdağ, Turkey

The native vegetation has taken over the operations supported by the complex structure of biological diversity reveals the cycle of a healthy ecosystem. For this reason, all of the physical and biotic factors in areas where native vegetation and an interaction of mutual. The native vegetation on the one hand living environments affected by factors other living and non-living, and their presence on the other hand constitute one of the most important 
factors in terms of diversity. Native plants that will blend the best of local environmental conditions, plant species, and above all a large scale ecological plantation of native plants provides significant contributions to native and biological communities. Aesthetic and functional characteristics of many native plants, as well as contribute to the efficiency of the soil, reduce erosion, and often less than many exotic plants, fertilizers, pesticides and other chemicals, such as input, show the need for maintenance measures. Plantation studies, native plants are becoming increasingly popular for many countries.

The main reasons for this interest;

Aesthetics: Beauty, interesting or rare forms and the native environment, establishing the connection.

Environment: Water use reduction, less pesticide and fertilizer use, the creation of a suitable environment for wildlife.

Maintenance: low long-term maintenance costs, and less work needed to increase the durability of the plant listed as heard.

The presence of native vegetation of the country's economy is the direct and indirect benefits of unlimited. A rich variety of plant species in the flora of Turkey, local people need to grow them, as well as industrial and scientific organizations, benefits for different purposes. Native vegetation, improving a country's climatic conditions and soil loss prevention in rural areas, preparing the ground for scientific research, forest products, food, and pharmaceutical industry is a source of units to meet the need for raw materials and fuel.

Especially important in the protection of endemics are carried out. Classes of endangered to which they belong are determined internationally, is under a lot of pressure given priority species which are in danger of extinction.

Threats to plants in Turkey are shown below. These factors are;

- Industrialization and urbanization,

Urbanization in rural areas is particularly damaging to vegetation

- Agricultural extension and excessive grazing

The native pasture areas, overgrazing, and prevents the growth of weeds as well as to the spread of cosmopolitan species are herbaceous origin. The animals eating the herbs roots up to their neck that prevents the growth of weeds and grass pastures deteriorate the quality of output. The inedible prickly weeds are spreading.

- $\quad$ Tourism

Dunes and coastal area to be occupied by tourism facilities

- $\quad$ Collecting plants from nature

Native plants are collected from nature for various purposes (medical, spices, ornamental, fuel, animal feed, especially bulbous plants) 
- Reclamation of Halophytic Areas

Large halophytic areas are improved, especially for agricultural purposes.

- Agricultural Control and Pollution

Unconscious use of agricultural pesticides. Especially in endemic and rare plants are damaged.

- Afforestation

Reforestation activities is changed environmental conditions of the plants. This activity is made of a plant endemic to the place where you are likely to disappearance.

- $\quad$ Fire

Fires can damage local and rare endemic species

The European continent in the Thrace Region, different climates, soil types, and due to the geographical characteristics of the floristic aspect is very rich. Although there are many different vegetation types in the Thrace Region, There are four main types:

1. Forest vegetation

2. Shrub vegetation

3. Meadow vegetation

4. Aquatic vegetation

\section{Tekirdağ and Ganos mountains}

Northwest Turkey Tekirdag, Marmara Sea, one of the three provinces in the north of the territory of the whole of Thrace, as well as two sea-coasts in Turkey is one of the six provinces. With a surface area of $6313 \mathrm{~km}{ }^{2}$, Istanbul, Tekirdag from the east, north, BSNL, west of Edirne, Canakkale south-west to the south, surrounded by the Sea of Marmara. North-east to the Black Sea is $2.5 \mathrm{~km}$ from the coast.

The geological structure of Tekirdağ is relatively young. area of the province while the sea covered the first time, the current image of the IV. from time. Increased Anatolia and Thrace, the Aegean Marmara and Black Sea basins lowered. Soils generally consist of sandstones containing clay and cemented.

Tekirdag, approximately 1,200 km long starting Karlıva 100-15000 m wide, consisting of the many faults of the North Anatolian Fault (NAF) is located near the end. $(15-25 \mathrm{~km})$. Faults may be caused by an earthquake within the boundaries of Tekirdag Province; Saros Gaziköy fault in the Sea of Marmara with the edges of the trench part of the fault. Ministry of Public Works and Settlement, dated 04.18.1996 "Seismic Zoning Map of Turkey" according to the outcrops, and Barbaros 1 Mürefte Degrees are in the earthquake area. 
Located in the southeastern part of the Balkan Peninsula in the Thrace region has a different morphological units. The most important of these morphological units in the province of Tekirdag Ganos and Koru Mountain (Figure 15).

Between these two mountainous terrain, river branches and split Ergene, mild, moderate, and sometimes pen plain steep slope lands in the south and middle parts are the high hills and sloping hillside land (Figure 16).

Ganos Mountain is located in the south of Thrace. Mountains, extends northeast-southwest direction. By Streams highly fragmented appearance. There are many hill and mountain villages in the region. Ganos Mountain is cool and a little rainy Mediterranean climate.
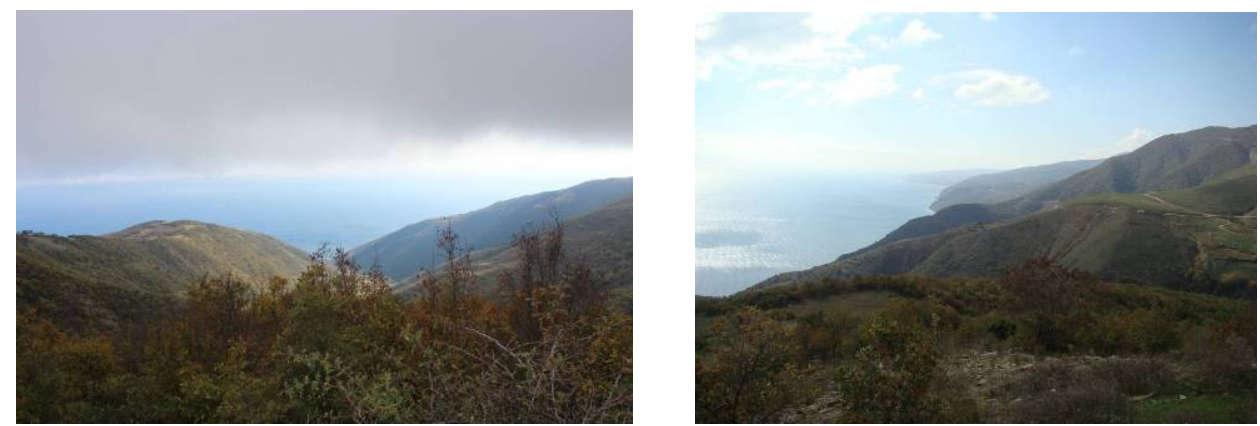

Figure 15. Morphological structure of Ganos mountains
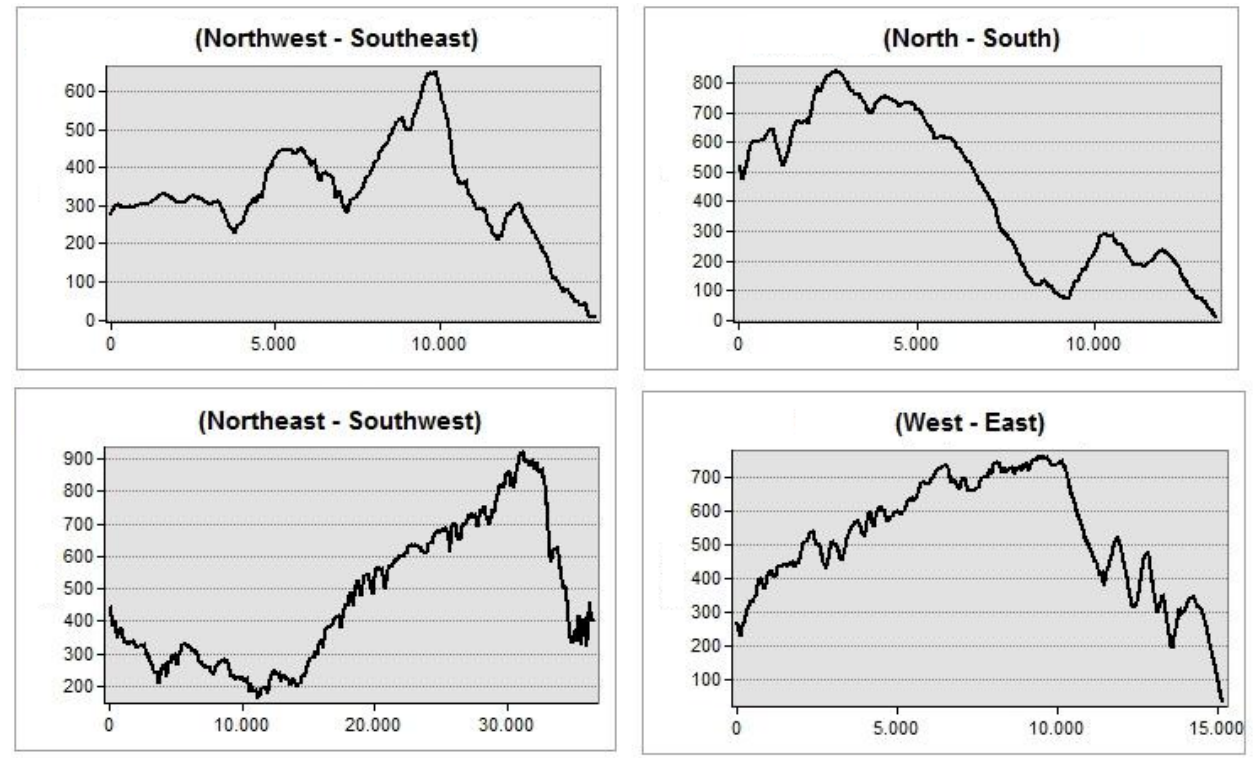

Figure 16. Profiles of Ganos Mountains, Tekirdağ, Turkey (Özyavuz, 2011) 
Therefore, there are so many taxa of Mediterranean origin. Ganos Mountain, Quercus sp. and Carpinus sp. representation of the Balkans, central Europe and the Euxine falls into the area of the dominant elements of the flora. In addition, shrubs Ganos Mountain foothills overlooking the Marmara Sea and the lowlands of the elements is observed that the pseudomaquis.

Constitute the most important Tekir Mountain the elevation of the province; $12 \mathrm{~km}$ south of the city of Tekirdag Kumbağ from the start, until to Gelibolu in a row $(60 \mathrm{~km})$ stretches. The highest point Ganos Mountain. The eastern part of the province is less high. Some of the ridges on the plains is slightly wavy. One of them is around Corlu, extends east-west direction. Line is part of a water basin that serves as a teenager, and this limits the ridge to the east foot of the Strandja Tekirdag regains the west. Istrancalar (Ganos Mountains), Çerkezköy starts and rises gradually to the north.

In inland areas covering the vast and fertile plains of river valleys are broad-based. The most important of these, from the western direction Çerkezköy, Ergene river flowing through the bed with an ever-expanding Ergene Plain Hayrabolu and Cene (Beşiktepe) alluvial deposits along the creeks and Maxillofacial Hayrabolu plains.

Small and narrow coastal plains along the shores of the Marmara, the materials brought by the rivers along the coast, is a result of the accumulation. Tekirdag, Ergene Despite the fact that the basin, vegetation, rainfall, due to lack of geological structure is sparse and has a network of small streams. Irregular flow regimes of rivers, and is proportional to the amount of rainfall and the regime. In the summer, the waters decreased drying grows in winter precipitation and snow melt, or even brimming. City streams Saros Gulf, the Sea of Marmara and the Black Sea is poured. Ergene important rivers of our city with the River Corlu, Hayrabolu, Işıklar, Olukbaşı and puddles streams.

$133 \mathrm{~km}$ along the coast of the Sea of Marmara Tekirdağ is the southern boundary. $2.5 \mathrm{~km}$ from the coast of the Black Sea, there are also. Marmara coast, leaving aside the small and narrow coastal plains, no generally high coasts. Marmaraereğlisi the only native harbor off the coast of Tekirdag. This is a peninsula. Marmaraereğlisi east of the port in the form of a semi-circle diameter of $1.600 \mathrm{~m}$. Northeasterly mouth open, the other winds are closed. To prevent severe winds and west southwest wind is a haven of refuge for boats.

Tekirdag province, Black Sea Kastro (Camlikoy) dating back to the bay and the bay Çilingoz high and steep rocky coastline has a view.

Does not exceed $100 \mathrm{~m}$ in the Gulf of Tekirdag depth. Self called a shallow sea. Rich in marine plants and animals. More than $1000 \mathrm{~m}$ in the Gulf Kumbağ'dan south west of the line will be drawn deeper. Fishermen here or com channel are also. And the actual currents through shoals of fish here.

Temperature averages and indices, given the general humidity, Tekirdağ province's climate is characterized as temperate semi-humid. The effect of distance and elevation coastal walks inland sea temperature and precipitation values are entered variations are small. 
Along the coast of the Sea of Marmara, summer is hot and dry, while winters are mild and rainy characteristics of the Mediterranean climate. However, the effect of the Black Sea climate lighter summer drought. During the winter season snowfalls are common. More arid inland summer is entered the semi-continental climate with cold winters more apparent.

Extending to the north of Tekirdag House Strandja more rainfall due to the mass of the northern slopes are covered with beech forests. In this section cover ormanalt1 rhododendrons (Rhododendron) creates. The further south, the southern slopes and, due to reduced rainfall, Fagus sp., Quercus sp. and Carpinus sp. seen that place.

Adolescents in the residential areas near the basin rarely leave the bus at the correct Quercus sp., Carpinus sp, Paliurus and Ulmus sp. populations are outstanding. These small groups of trees, whether Thrace is a testament to the inner sections of the steppe area. Thrace region, as a result of the destruction of forests to make farmland, today has the appearance of steppe land. (Anthropogen step) In this section and in the valleys of the land base poplar and willow species are common (Figure 17).
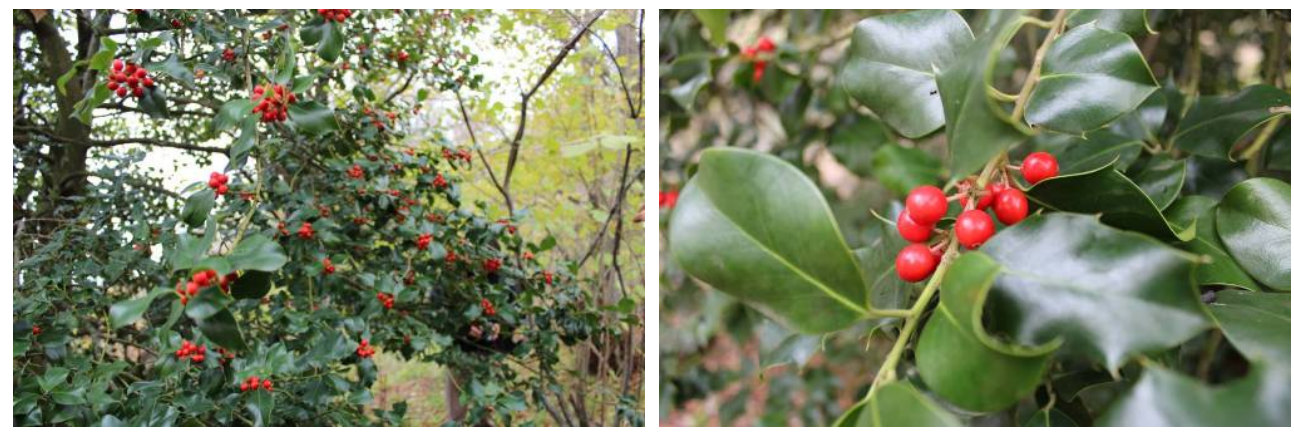

Figure 17. Ilex aquifolium L.

The northern slopes of the mountains of southern Ganos, Carpinus sp., Quercus sp., Tilia sp., and under dense forest cover evident, due to reduced rainfall in the southern slopes are dry forests and scrub communities. Quercus sp. and Pinus sylvestris sp. forests in the Ganos Mountains communities are dominant.

\section{Conclusion}

As a result of the researches of the Ganos Mountain, 202 genera and 64 families, 305 plant taxa were included in these genera. Compositae families in terms of richness of species in this family are the most important. This is followed by Leguminosae family. Ganos Mountain taxa of flora distribution of parts of the Euro-Mediterranean elements with the elements of Sibirian comes first. Tekirdağ can be shown poor in terms of forest. Istranca mountains fall within provincial areas, in places, are oak groves. In some areas, Alnus sp, Ulmus sp. and Pinus species where observed. Typical plants are Mediterrean Climate maquis, vineyards, fruit orchards and olive groves. Plants identified in this study are shown below; 
Acer campestre L. subsp. Campestre, Alkanna tinctoria Tausch, Arbutus andrachne L, Asparagus acutifolius L., Briza maxima L., Calycotome villosa (Poir) Lk., Capparis spinosa L., Carpinus betulus L., Carpinus orientalis Miller, Cersis siliquastrum L, Cistus creticus L., Colutea cilicica Boiss.et Bal., Coronilla emerus subsp. Emeroides, Cercis siliquastrum L., Cistus creticus L., Clematis vitalba L., Colchicum autumnale L., Colutea cilicica Boiss.et Bal. Cornus mas L., Crataegus monogyna L., Cydonia oblonga Miller, Dittrichia viscosa L. Greuter, Doronicum orientale HOFFM., Emerus majus Mill., Euphorbia rigida Bieb., Euphorbia characias subsp.wulfenii, Ferula communis subsp. Communis, Fraxinus ornus L. subsp. ornus, Glaucium flavum Crantz, Hymenocarpus circinnatus L. Savi, Hypericum perforatum L., İlex aquifolium L., Jasminum fruticans L., Juncus acutus L., Juniperus oxycedrus L. subsp. oxycedrus., Phyllrea latifolia L. Prunus spinosa L. subsp. dasyphylla., Quercus frainetto Ten., Quercus infectoria Olivier, Quercus petraea (Mattuschka) Liebl. subsp. Petraea, Muscari armeniacum Leichtlin Ex Baker, Nasturtium officinale L., Paliurus spina-christi Mill., Parietaria officinalis L., Phyllirea latifolia L., Pistacia terebinthus L. Platanus orientalis L., Ruscus hypoglossum L., Salix viminalis L., Salvia triloba L., Sambucus ebulus L., Sarcopoterium spinosum (L.) SPACH., Scorpiurus muricatus L. Fiori., Seseli tortuosum L., Smilax excelsa L., Spartium junceum L., Tamus communis L., Thymelaea tartonraira L., Thymus atticus Celak., Tilia argentea Desf. (Korkut, 1987; Özyavuz, 2011)
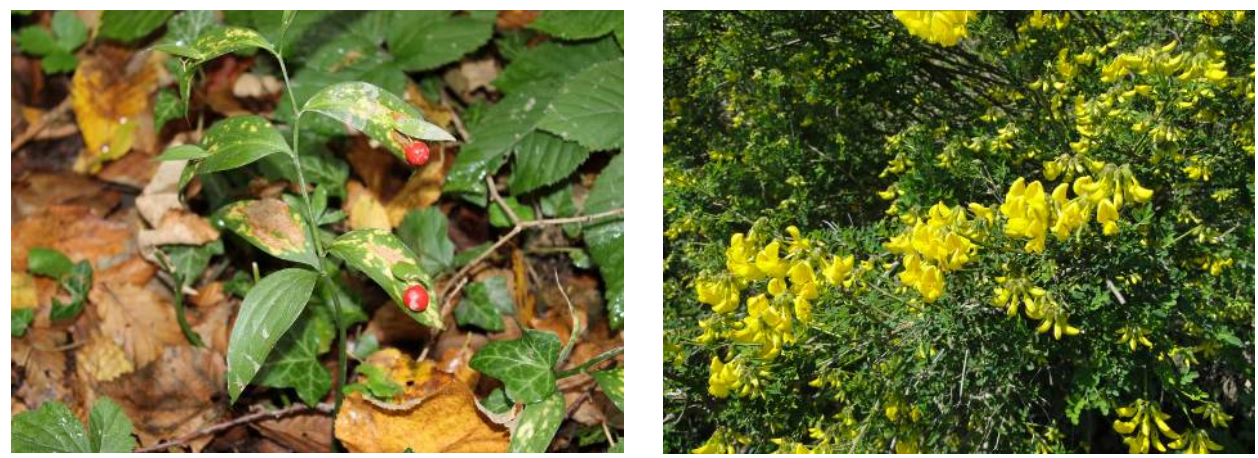

Figure 18. Ruscus hypoglossum $L$

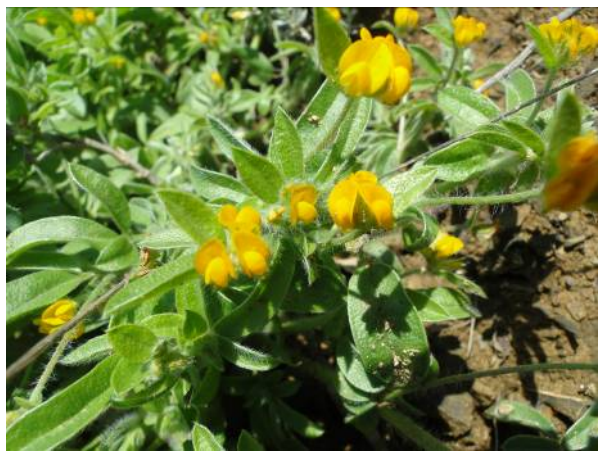

Figure 19. Emerus majus Mill.

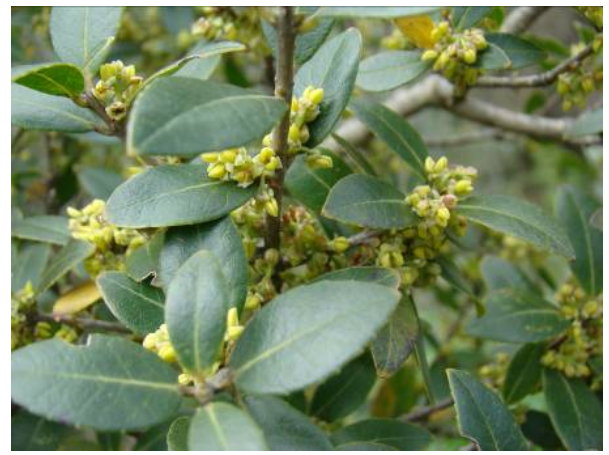

Figure 20. Hymenocarpus circinnatus L.

Figure 21. Phyllrea latifolia L.. 

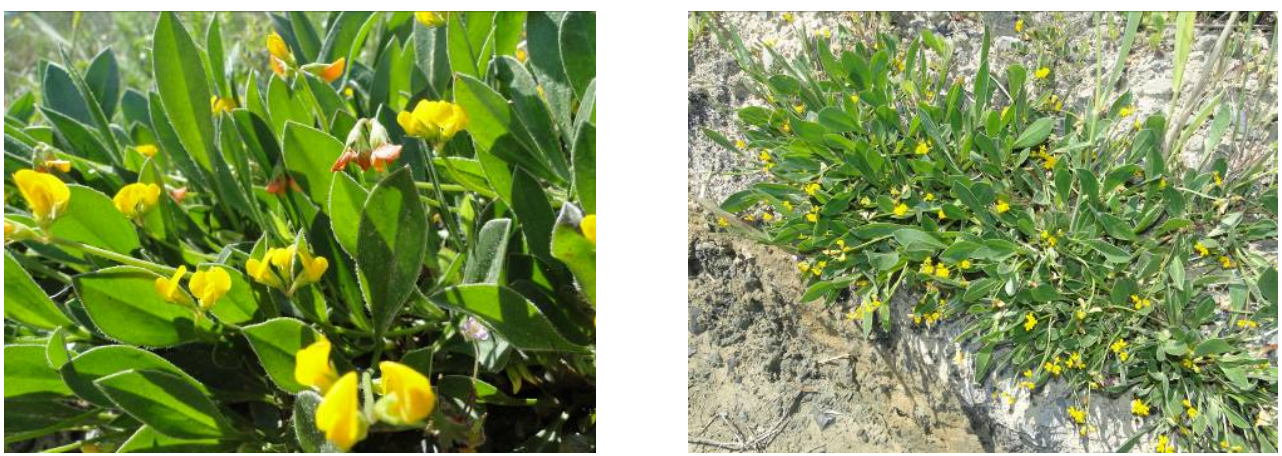

Figure 22. Scorpiurus muricatus L. Fiori.

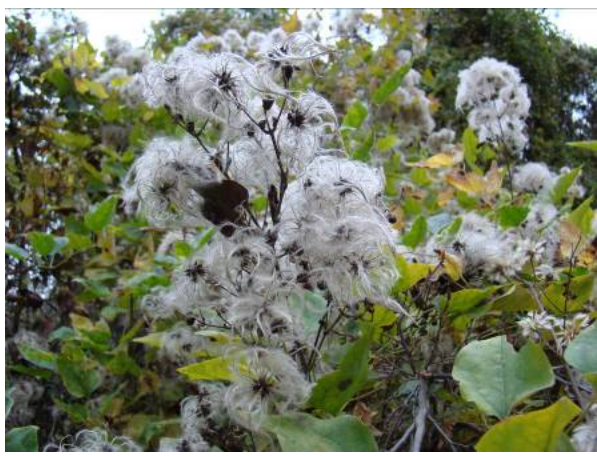

Figure 23. Clematis vitalba $L$.

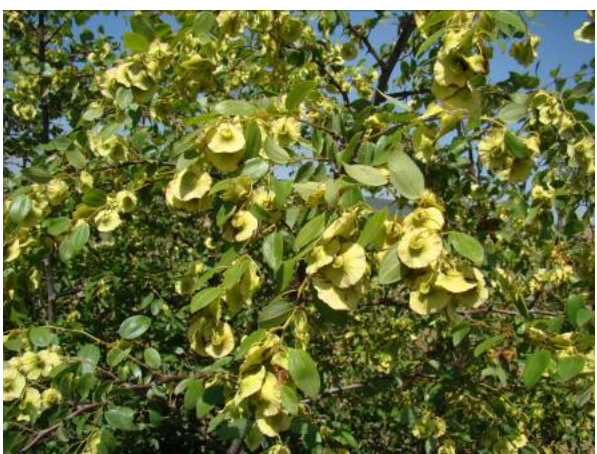

Figure 25. Paliurus spina-christi Mill

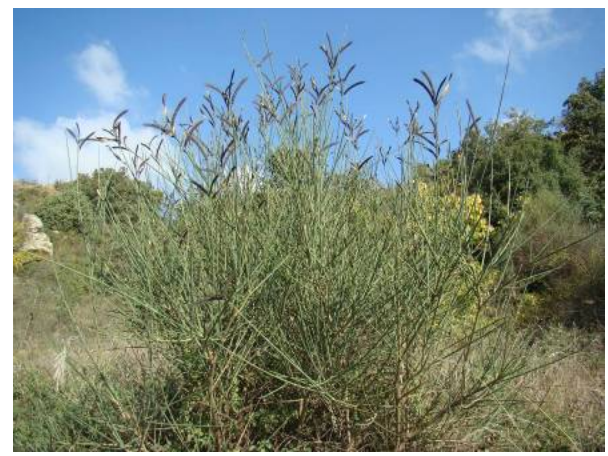

Figure 24. Spartium junceum L.

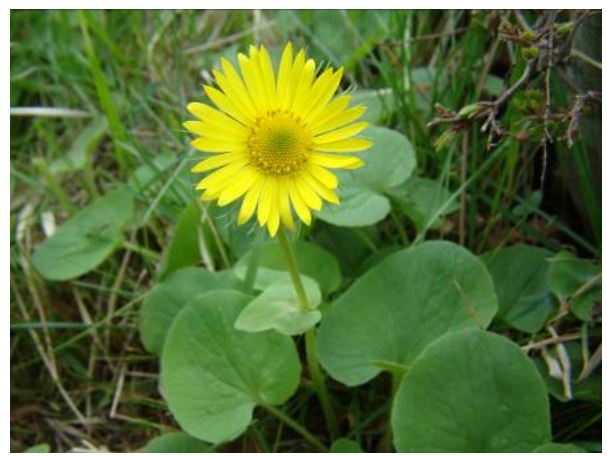

Figure 26. Doranicum orientale Hoffm. 


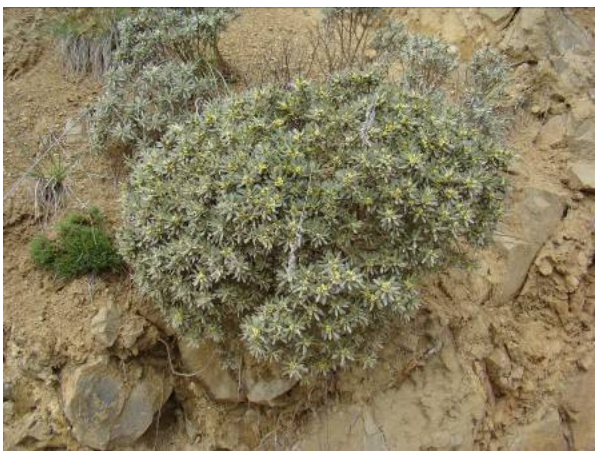

Figure 27. Thymelaea tartonraira L.

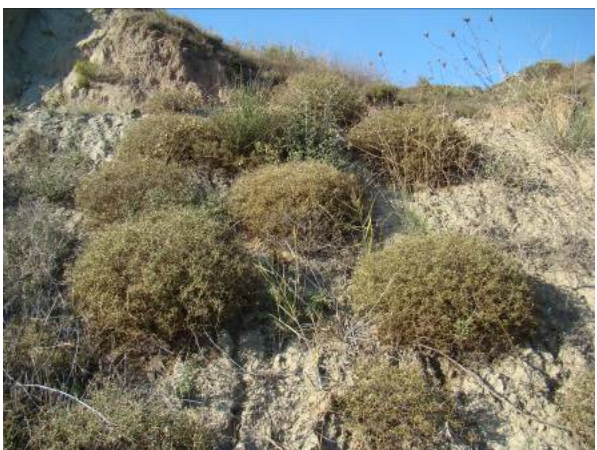

Figure 29. Sarcopoterium spinosum (L.) SPACH.

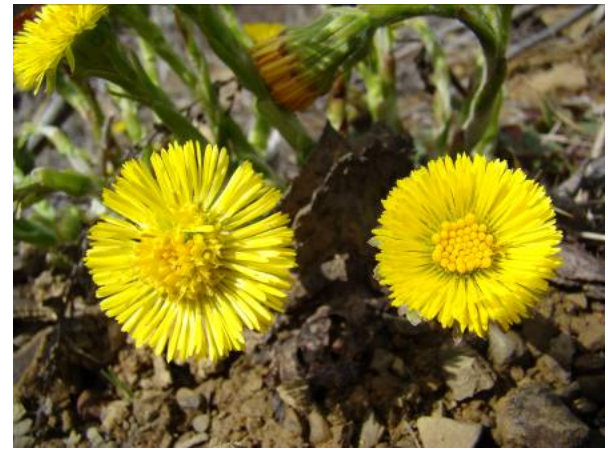

Figure 28. Tussilago farfara L..

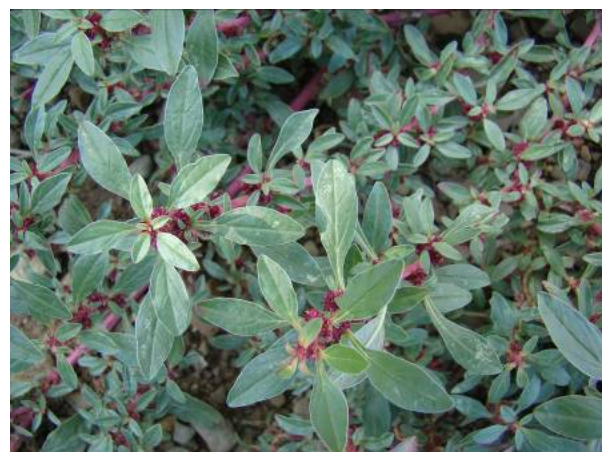

Figure 30. Parietaria $s p$.

\section{Author details}

Murat Özyavuz and Aslı B. Korkut

Namık Kemal University, Faculty of Fine Arts, Design and Architect, Department of Landscape Architecture, Turkey

Ayten Özyavuz

Namık Kemal University, Turkey

\section{References}

Environmental Protection Authority, 2000. Clearing Of Native Vegetation, With Particular Reference To The Agricultural Area, Environmental Protection Of Native Vegetation In Western Australia Position Statement No. 2, 15 p.

Korkut, A. 1987. Trakya Bölgesi Doğal Bitki Örtüsünde Peyzaj planlama Çalışmaları Yönünden Değerlendirilebilecek Bazı Bitkisel Materyalin Saptanması, TÜBİTAK Tarım ve Ormancilık Araştırma Grubu Proje no: TOAG-581, Tekirdağ. 
National Wildlife Federation, 2013. What is Biodiversity?, http://www.nwf.org/wildlife/ wildlife-conservation/biodiversity.aspx.

Özyavuz, A. 2011. Determınatıon of some plants grown in natural vegetatıon in Tekırdağ (kumbağ-sarköy between) Coastlıne and usage Opportunitıes in landscape architecture, MSc. Thesis, Namik Kemal University, Graduate School of Natural and Applied Sciences, Department of Landscape Architecture, Turkey.

Özyavuz, M. 2011. Analysis with Geographic Information Systems and Remote Sensing Techniques, Ecological Conditions of Vegetation, Ganos (Işıklar) Mountain (Tekirdağ), Journal of Tekirdag Agricultural Faculty, 8(2), p.37-48.

Peter L. Smith, Brian Wilson, Chris Nadolny, Des Lang. 2000. The ecological role of The native vegetation Of new south Wales, Native Vegetation Advisory Council, 60 p.

Productivity Commission 2004, Impacts of Native Vegetation and Biodiversity Regulations, Report no. 29, Melbourne.

Slattery, Britt E., Kathryn Reshetiloff, and Susan M. Zwicker. 2003. Native Plants for Wildlife Habitat and Conservation Landscaping: Chesapeake Bay Watershed. U.S. Fish \& Wildlife Service, Chesapeake Bay Field Office, Annapolis, MD. 82 pp.

Smith, P. L., Wilson, B., Nadolny, C. 2000. The ecological role of the native vegetation of new south Wales, Native Vegetation Advisory Council, 60 p.

Victorian Government Department of Sustainability and Environment, 2012. Future directions for native vegetation in Victoria Review of Victoria's native vegetation permitted clearing regulations, ISBN 978-1-74287-616-0 (online), $36 \mathrm{p}$.

Virginia Department of Conservation \& Recreation, 2012. Native Plants for Conservation, Restoration, and Landscaping, http://www.dcr.virginia.gov/natural_heritage/ nativeplants.shtml 